\title{
СИСТЕМНЕ УПРАВЛІННЯ ПРІОРИТЕТНИМИ НАПРЯМАМИ РОЗВИТКУ ФЕРМЕРСЬКИХ ГОСПОДАРСТВ I СІЛЬСЬКОГОСПОДАРСЬКИХ ПІДПРИЄМСТВ
}

\author{
Скрипник Світлана Валентинівна \\ кандидат економічних наук, доцент \\ Херсонський державний аграрний університет (м. Херсон, Україна) \\ ORCID: 0000-0003-3004-6117 \\ skrypnik-s@ukr.net
}

\begin{abstract}
У статті досліджено сутність системного управління пріоритетними напрямами розвитку фермерських господарств і сільськогосподарських підприємств. При цьому як система з певним набором підвидів, функиій, інструментів розглядається управління та як системні утворення - суб'єкти господарювання. Важливими складниками системного управління визначені функціональне, процесне й управління за центрами відповідальності. їх залучення є найбільш перспективним щодо пріоритетних напрямів розвитку фермерських господарств і сільськогосподарських підприємств. Вони дозволяють використовувати спеціальні інструменти, методи та прийоми, адекватні змісту пріоритетних напрямів. При цьому в інфрормаційно-аналітичному забезпеченні управлінських рішень велика увага приділяється моніторингу та обліку господарської діяльності.
\end{abstract}

Ключові слова: фермерські господарства, сільськогосподарські підприємства, пріоритетні напрями, розвиток, системне управління, складники, моніторинг, обліково-аналітичне забезпечення.

DOI: https://doi.org/10.32845/bsnau.2019.4.16

Постановка проблеми. В умовах посилення конкурентних чинників у діяльності суб'єктів господарювання аграрного сектору економіки зростає роль і значення ефективного управління бізнесовими, виробничими, екологічними, соціально-економічними процесами. Тому впровадження у фермерських господарствах та сільськогосподарських підприємствах системного управління як одного із основоположних інструментів здійснення організаційно-економічних пріоритетів ї розвитку має велике і теоретичне, і практичне значення.

Системне управління, згідно загальноприйнятих уявлень, грунтується на уявленнях про керуючі та керовані суб'єкти як системи. Система перша означає розуміння господарств і підприємств як відкритих складноорганізованих системних утворень із упорядкованою структурою на основі тих або інших взаємозв'язаних підрозділів. Система друга означає розуміння власне управління або менеджменту як системи, яка складається з системних компонентів, - заходів, прийомів, методів, механізмів, управлінських рішень.

У такому визначенні вони забезпечують здійснення процесу сільськогосподарського відтворення, а системні складники господарств і підприємств $є$ його основою. Тому $є$ підстави вважати про здійснення у межах системного й процесного управління, яке відповідає за втілення останнього. Процесне управління, яке здійснюється за центрами відповідальності, містить елементи контролінгу як міжфункціонального напряму управлінської діяльності. Також у межах системного управління можна реалізувати й ситуаційний підхід та відповідне йому ситуаційне управління. Воно направлене на вирішення тих або інших ситуацій, які чинять найбільший вплив на ефективність та конкурентоспроможність діяльності фермерських господарств та сільськогосподарських підприємСтв.

Крім вказаного, у відповідності до концепції системного управління реалізується функціональне (з орієнтацією на відповідних його завданням функціональних виконавців або функціональні підрозділи); тактичне (направлене на вирішення повсякденних оперативних або тактичних завдань); стратегічне (направлене на забезпечення основоположних цілей і завдань на перспективу) управління. Основою ж здійснення системного управління та його складників або будьяких інших видів $є$ інформація, оцінка та аналіз і діагностика. Вони забезпечуються моніторингом, тобто спостереженням та обліком всіх видів діяльності.

Моніторинг та облік діяльності суб'єктів аграрного господарювання повинен бути щоденним, послідовним, системним; здійснюватись за певними правилами, показниками та критеріями. Цим вимогам найбільшою мірою відповідають фінансовий та управлінський облік. Забезпечення управлінського обліку спрямоване на реалізацію інформаційних потреб управління підприємства й базується на оперативній обробці внутрішньої інформації та прийнятті своєчасних управлінських рішень щодо власне його здійснення. Водночас, сучасні умови господарювання ставлять акцент на спрямованість та управлінську орієнтацію обліку, зокрема у сільськогосподарських підприємствах, що підкреслює особливу актуальність і складність вирішення цієї проблеми.

Аналіз останніх досліджень і публікацій. Проблеми впровадження управлінського обліку в практику діяльності вітчизняних підприємств та управління нею i, зокрема, обліку за центрами відповідальності досліджували такі відомі вітчизняні і зарубіжні науковці як Бланк О.І., Голов С.Ф., Друрі К., Каверіна, О.Д., Мармуль Л.О., Нападовська Л.В., Палій В.Ф., Плаксієнко В.Я., Пушкар М.С., Савчук В.П., Садовська І.Б., Шеремет А.Д., Аткінсон Е., Хорнгрен Ч.Т., Фостер Дж. та ін. Хоча наукові розробки названих та інших авторів $€$ досить різносторонніми в теоретичному, методологічному, методичному та практичному аспектах, однак залишаються недостатньо вивченими й потребують поглибленої розробки питання організаційно-методичного забезпечення із впровадження обліку та формування внутрішньої звітності за центрами відповідальності для потреб системного управління.

Формулювання цілей статті. Метою статті $€$ визначення змісту, складників, особливостей, функцій та завдань системного управління пріоритетними напрямами розвитку фермерських господарств і сільськогосподарських підприємСтв. 
Виклад основного матеріалу дослідження. Багатогалузевий характер сучасних агробізнесових структур вимагає побудови та дотримання принципу гнучкості системного управління з метою зниження витрат та прийняття обґрунтованих управлінських рішень внаслідок зростання потоків оперативної інсооммації та потоку адміністративних розпоряджень і вказівок. Удосконалення організаційно-економічного механізму функціонування господарств і підприємств агросектору, досягнення організаційно-економічних пріоритетів їх розвитку ґрунтується також на децентралізації системного управління.

Саме її можливості дозволяють розподілити повноваження із прийняття рішень між різними рівнями або функціональними підрозділами та центрами відповідальності щодо планування й контролю доходів та витрат. Також це допомагає виявляти проблеми, ризики або/та ефективність діяльності кожного структурного підрозділу підприємства, здійснювати контроль і планування сукупності різних фінансово-економічних і господарських показників, аналізувати відхилення фактичних від запланованих значень.

Узагальнюючим поняттям при децентралізації системного управління Шеремет А.Д. називає «центр відповідальності» [1, с. 276], який дозволяє розглядати організаційну структуру сучасного фермерського та аграрного підприємства як сукупність різних центрів відповідальності, пов'язаних процесами або лініями відповідальності. Оскільки при децентралізації управління можливо охоплювати всі структурні одиниці зверху донизу і визначати місце кожної структурної одиниці (підрозділу, відділу, сегменту, фахівця) з точки зору делегування їм відповідних функціональних повноважень і відповідальності. Таким чином, наголос здійснюється на використанні процесного та функціонального підходів у системному управлінні досягненням організаційно-економічних пріоритетів.

Нападовською Л.В. визначено, що центрами відповідальності $€$ існуючі структурні елементи діяльності підприємств і господарств на чолі з відповідальним керівником [2, c. 489]. Зокрема, виділення центрів відповідальності науковці пов'язують із розподілом повноважень між працівниками підприємства та наданням керівникам підрозділу прав самостійно приймати рішення, закріпленням відповідальності за наслідки таких рішень.

Важливим аспектом обліку як основи системного управління Хорнгрен Ч.Т. і Фостер Дж. [3, с. 247] вважають виділення окремих підрозділів у якості об'єктів обліку, оскільки центри відповідальності $€$ тими підрозділами, за якими можливо обліковувати виконання їх менеджерами чітко встановлених обов'язків. Отже, децентралізація управління не лише дозволяє визначати місце кожного структурного підрозділу в інформаційному просторі, делегуючи йому певні повноваження і відповідальність. Вона являє собою якісно новий тип системного управління, спрямований на максимізацію прибутків та ефрективності господарювання загалом.

В організаційній структурі суб'єктів господарської діяльності аграрного сектору економіки функціонують різні структурні підрозділи (центри відповідальності) - ланки, механізовані загони, бригади, відділи, служби, керівники яких несуть повну відповідальність за результати діяльності своїх підрозділів і контролюють їх. Система обліку за центрами відпові- дальності дає змогу оцінювати діяльність таких центрів відповідальності та їх керівників на підставі зібраної, накопиченої, проаналізованої і представленої інформації про їх витрати та результати. Визначення науковців щодо центрів відповідальності дозволили узагальнити характерні ознаки системи обліку за центрами відповідальності.

Таким чином, у наукових працях системне управління за центрами відповідальності (процесне управління, процесний контролінг) грунтується на використанні обліку витрат за центрами відповідальності і місцями їх виникнення. При цьому облік зазначається не лише як внутрішній інструмент контролю виробничих витрат окремих підрозділів, а й як основа для оцінки ефективності діяльності підприємств та господарств у цілому. В організаційному процесі фрермерських господарств і сільськогосподарських підприємств їх поділ на структурні підрозділи можна розглядати як один із його досить важливих теоретичних і практичних аспектів [4, с. 55]. Адже колективи працівників виробничих підрозділів $\epsilon$ об'єктами управлінського впливу з боку їх керівників (менеджерів) i, водночас, об'єктами планування, моделювання й прогнозування.

Іншим важливим теоретичним і практичним аспектом системного управління здійсненням організаційно-економічних пріоритетів розвитку підприємств і господарств $€$ комунікаційні зв'язки його різних рівнів, виходячи із їх взаємовідносин та повноважень структурних підрозділів. Тому, враховуючи особливості організаційної структури аграрного підприємства або фермерського господарства, загальну систему центрів відповідальності (витрат) можна розглядати за двома групами: технологічні центри витрат і дискреційні центри витрат, а саме:

1. Технологічні центри відповідальності або витрат:

- центри витрат основного виробництва (рослинництво та його галузі; тваринництво та його галузі; переробка та її галузі);

- центри витрат допоміжного виробництва (ремонтна майстерня; вантажний автотранспорт; електропостачання; водопостачання; теплопостачання, ін.);

- центри витрат обслуговування виробничих процесів (машинно-тракторний парк; холодильне обладнання; елеваторне господарство; сільгоспхімія тощо).

2. Дискреційні центри витрат представлені наступними підрозділами:

- центр адміністративних витрат;

- центр маркетингово-збутових витрат.

Безумовно, закріплення центрів відповідальності (витрат) за виділеними сегментами діяльності в організаційній структурі фрермерських господарств і сільськогосподарських підприємств буде впливати на: організаційну структуру системного управління, побудовану на основі центрів відповідальності; робочий план бухгалтерських рахунків; порядок документообігу [5, с. 25]. Тому для організації обліку за центрами відповідальності необхідно передбачити специфіку його ведення в обліковій політиці господарств і підприємств. Зокрема, йдеться про розробку плану рахунків за центрами витрат; групування витрат за центрами за їх складом та різноманітністю; розподіл центрів витрат на основні й допоміжні, первинні й вторинні, основні і супутні, постійні та змінні; удосконалення або зміну (доповнення, скорочення) форм внутрішньої звітності тощо. 
Таким чином, управлінська політика господарств і підприємств щодо організації обліку як інформаційно-аналітичної основи системного управління за центрами відповідальності має містити інфрормацію про: планово-оціночні показники діяльності центрів відповідальності; затверджені норми і нормативи, їх дотримання або відхилення, сезонні коливання; можливість використання трансфертних цін; відображення на бухгалтерських рахунках та у балансі результатів діяльності центрів відповідальності; їх інтерпретація в обліково-фрінансовій звітності.

Для оцінки та аналізу ефективності діяльності центрів відповідальності фермерських господарств і сільськогосподарських підприємств необхідним $є$ вибір показників оцінювання, що залежить, насамперед, від типу такого центру [6, с. 26]. Діяльність центрів витрат оцінюється, переважно, на основі аналізу відхилень від планових або стандартних витрат. Так, діяльність центрів прибутків оцінюється на підставі звіту про фінансово-економічну та виробничу діяльність, який відображає прибуток кожного центру. Діяльність центрів доходів визначається за обсягами і структурою продажів продукції або послуг.

Орієнтиром діяльності і засобом оцінки кожного центру відповідальності є своя група або сукупність кількісних показників. Вони закріплюються за кожним центром відповідальності (витрат) у відповідності до поставлених пріоритетних цілей, завдань, напрямів їх розвитку для забезпечення єдиних (загальних) пріоритетів розвитку підприємств і господарств, у структурі яких вони перебувають. У бухгалтерському обліку діяльність центрів відповідальності як об'єктів системного управління буде відображатися шляхом формування кількісних показників, сукупність яких становить інформаційну модель цієї діяльності. Тому виділення фактичних і оціночних показників, включення їх в інформаційні потоки в системі внутрішньо-виробничих планів й звітів $€$ важливою умовою організації обліку за центрами відповідальності [7, с. 62].

Оцінку діяльності центрів відповідальності фермерських господарств і сільськогосподарських підприємств здійснюється також із дотриманням певних критеріїв або вимог (рис. 1).

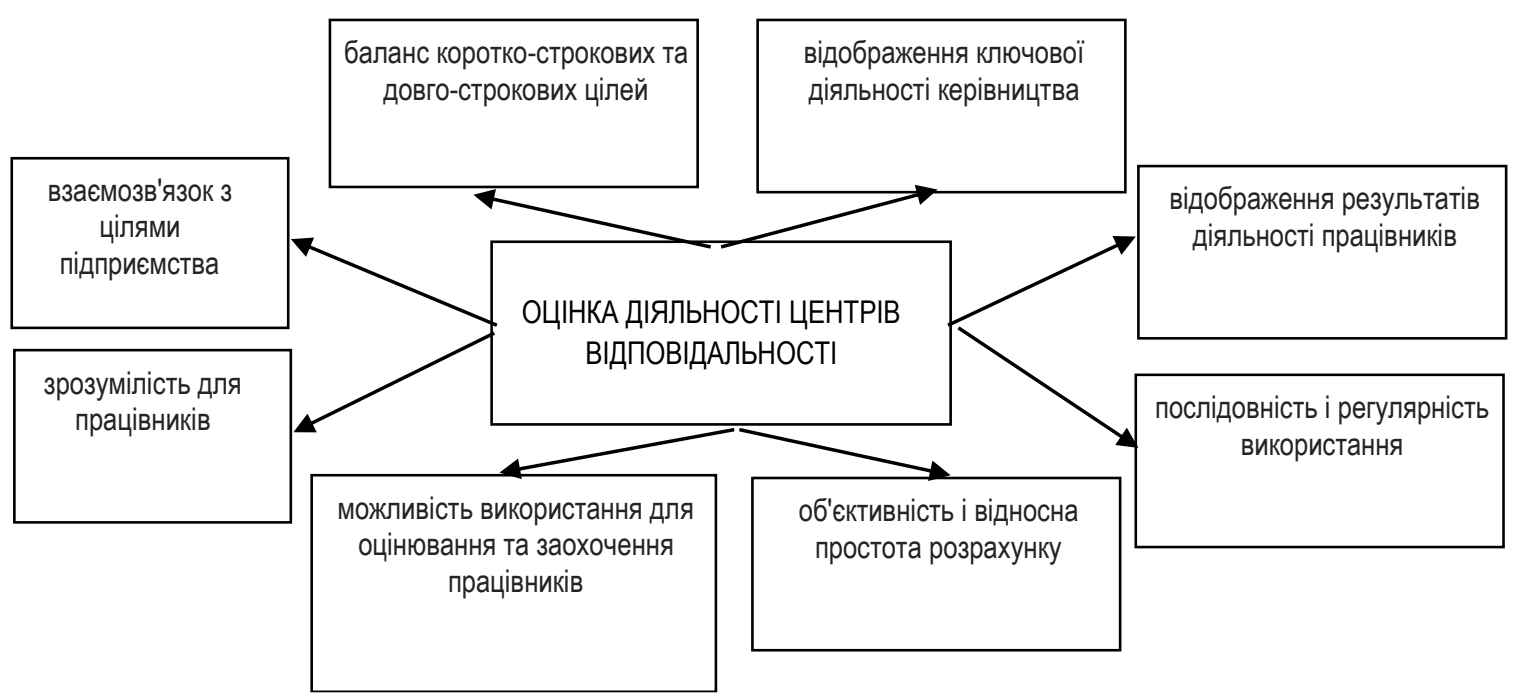

Рис. 1. Критерії оцінки діяльності центрів відповідальності фермерських господарств і сільськогосподарських підприємств

Так, наприклад, для оцінки діяльності центру відповідальності «Відділ матеріально-технічного постачання» можуть бути обрані такі групи показників: а) постачання обсяги (забезпечення) виробничого процесу паливно-мастильними матеріалами, запасними частинами, матеріалами сільськогосподарського призначення (в т.ч. показники забезпеченості й виконання договорів у процесі виробництва); б) обсяги витрати на поставку виробничих запасів за видами; в) ліміти виробничих запасів [8, с. 176].

Загальноприйнято, що у системі обліку за центрами відповідальності доцільно передбачати:

1) визначення центрів відповідальності за їх видами, функціями та спеціалітетом;

2) складання бюджетів (планів чи нормативів) для кожного центру відповідальності;

3) регулярне складання у центрах відповідальності звітів про аналіз та результати їх роботи у порівнянні із запланованими показниками діяльності.

Необхідною передумовою створення у фермерських господарствах та сільськогосподарських підприємствах дієвої системи моніторингу, внутрішньої звітності та оцінки, аналізу й діагностики є вивчення тих завдань, які вирішуються керівниками різних підрозділів, та виявлення потреб в їх інформаційному забезпеченні. А це, здебільшого, забезпечується для організації та здійснення самоконтролю керівників центрів відповідальності.

Їх засобом є формування інформаційної бази у системі внутрішньої звітності суб'єктів аграрного господарювання. Передусім, складаються інформаційні блоки (карти), які містять інфрормацію про діяльність структурних підрозділів [9, с. 91]. Для здійснення бухгалтерського обліку за центрами відповідальності збирають інформацію про витрати і доходи за кожним окремим центром. Це відбувається з метою виявлення відхилень або проблем, встановлення причин відхилень (проблем) та відповідальних за це осіб.

У науковій економічній, обліковій та управлінській літературі єдиний підхід до трактування внутрішньої звітності підприємств і, зокрема, звітності центрів відповідальності, не сформований. Більшість науковців та практиків використовують поняття «управлінська звітність», «управлінська бухгалтерська звітність», «внутрішня бухгалтерська звітність», «внутрішня управлінська звітність». Однак на сьогоднішній день необхідна конкретизація і самого трактування, і структури, змісту та форми внутрішньої звітності для забезпечення 
оперативною інформацією керівників центрів відповідальності різних рівнів та керівництва й власників фермерських господарств і сільськогосподарських підприємств загалом. Тому внутрішня звітність центрів відповідальності має відповідати певним вимогам і бути систематизованою за певними ознаками (рис. 2).

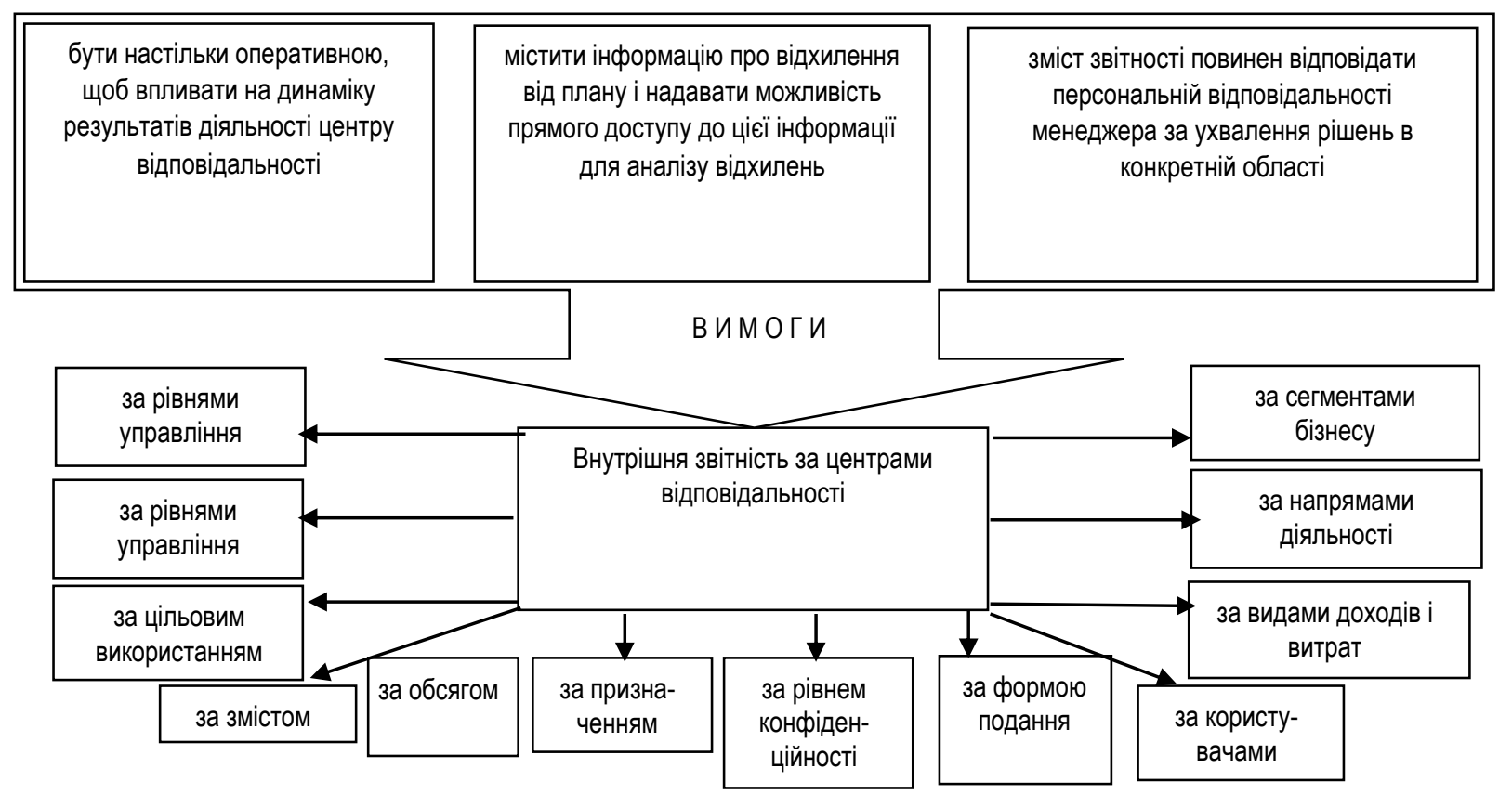

Рис. 2. Вимоги до внутрішньої звітності центрів відповідальності та її види у фермерських господарствах і сільськогосподарських підприємствах

Ефективність використання системного управління у забезпеченні організаційно-економічних пріоритетів розвитку фермерських господарств і сільськогосподарських підприємств визначається його принципами [10, с. 85]:

1. Принцип багатоплановості полягає у тому, що будьякий об'єкт розглядається у декількох планах, аспектах. Наприклад, як якісна одиниця, що має свої специфічні особливості, як частина своєї макросистеми та інші.

2. Принцип багатомірності полягає у тому, що будьякий складний об'єкт характеризується великою сукупністю властивостей, які об'єднані в групи (кластери), кожен з яких описує ті чи інші його особливості.

3. Принцип ієрархічності полягає у тому, що вивчення складних об'єктів має базуватися на уявленні про ієрархічності їх структури, а саме на уявленні про розміщення частин або елементів цілого у порядку від вищого до нижчого. Ієрархічну структуру мають не тільки моделі складу системи (системи - підсистеми-елементи), а також властивості якості цих систем та критерії, що використовуються для їх оцінки.

4. Принцип різнопорядковості властивостей полягає у тому, що ієрархічність будови системи та її властивостей породжує закономірності різного порядку. Одні закономірності притаманні усім рівням ієрархії, а саме усій системі. Інші належать тільки деякій групі рівнів, треті притаманні тільки елементам одного рівня, а четверті - тільки для окремих елементів одного рівня.

5. Принцип динамічності полягає у тому, що системний підхід вимагає розглядання досліджуваних об'єктів у їх розвитку на всіх етапах життєвого циклу.

Висновки. Визначено, що основоположним інструментом управління здійсненням організаційно-економічних пріоритетів розвитку фермерських господарств і сільськогоспо- дарських підприємств є системне управління. Воно передбачає розуміння об'єктів управління як складноорганізованих відкритих системних утворень з відповідними складниками, структурними підрозділами (галузевими, територіальними, функціональними); центрами відповідальності; взаємовідносинами (внутрішніми та зовнішніми), зв'язками між ними та процесами. Концепція системного управління у його складі дозволяє застосовувати процесний, ситуаційний та функціональний підходи та відповідні їм види управлінської діяльності.

Однією з переваг системного управління є застосування в якості інформаційно-аналітичної основи всебічної, достовірної, своєчасної, системної та послідовної інформації, оцінки, аналізу й діагностики. На нашу думку, їх можуть забезпечити моніторинг діяльності, а також управлінський облік за центрами витрат або відповідальності. В такому трактуванні останній знаменує контролінг як міжфункціональний інструмент - складник системного управління. Він дозволяє не тільки обліковувати та здійснювати оцінку, аналіз і діагностику витрат за центрами відповідальності, але й контролювати їх. При впровадженні системного управління береться до уваги наявність та специфріка у структурі господарств і підприємств і виробничих або господарських галузевих, і господарських територіальних підрозділів.

Ефективність використання системного управління у забезпеченні організаційно-економічних пріоритетів розвитку фермерських господарств і сільськогосподарських підприємств визначається також його принципами: багатоплановості, багатомірності, ієрархічності, різнопорядковості властивостей, динамічності. Окрема увага має приділятися принципу демократичного централізму, що означає делегування управлінських повноважень структурним підрозділам, центрам відповідальності, функціональним управлінцям або 
відділам.

\section{Список використаної літератури.}

1. Шеремет А.Д. Управленческий учет: учеб. пособие. М.: ИД ФБК-ПРЕСС, 2001. 512 с.

2. Нападовська Л.В. Управлінський облік: підруч. для вузів. К.: Київ. нац. торг.-екон. ун-т, 2010. 648 с.

3. Хорнгрен Чарльз Т., Дж. Фостер. Бухгалтерский учѐт: управленческий аспект [пер с англ. О.Д. Кавериной, И.В. Романовского];под ред. Я. В. Соколова; [пер. с англ.]. М.: Финансы и статистика, 2003. 416 с.

4. Бєляєва Н.С. Стратегія підприємства як елемент механізму стратегічного управління. Науковий вісник Херсонського державного університету. Серія «Економічні науки». 2015. С. 54-56.

5. Мармуль Л., Лугова О. Методичні підходи до оцінки економічного потенціалу сільськогосподарських підприємств. Економіст. 2012. № 2. С. 24-26.

6. Горіховський М.В. Використання форсайт-технологій в управлінні фермерським господарством. Науковий вісник Ужгородського національного університету. Серія: Міжнародні економічні відносини та світове господарство. 2017 . № 11. C. 24-27.

7. Романюк І.А. Нові чинники та концепції здійснення інтенсифікації сільського господарства. Вісник Бердянського університету менеджменту і бізнесу. 2016. № 4 (36). С. 60-63.

8. Малік М.Й., Нужна О.А. Конкурентоспроможність аграрних підприємств: методологія і механізми: монографія. К.: ННЦ «IAE», 2007. $270 \mathrm{c}$. $87-93$

9. Авраменко Ю.О. Оцінка конкурентоспроможності фрермерських господарств. Ефективна економіка. № 4. 2017. С.

10. Ігнатенко М.М. Формування інформаційної безпеки підприємств і організацій в умовах автоматизації обліку та фінансової звітності. Вісник Бердянського університету менеджменту і бізнесу. 2017. № 4 (40). С. 84-88.

Skrypnyk S.V., PhD, Associate Professor, Kherson State Agrarian University (Kherson, Ukraine)

System management of priority areas of development of farms and agricultural enterprises

The article examines the essence of system management of priority areas of development of farms and agricultural enterprises. At the same time, as a system with a certain set of subspecies, functions, and management tools, it is also considered as system entities - economic entities. The important components of system management are defined as functional, process, and responsibility center management. Their involvement is the most promising in relation to the priority areas of development of farms and agricultural enterprises. They allow you to use special tools, methods and techniques that are appropriate to the content of priority areas. At the same time, in the information and analytical support of management decisions, much attention is paid to monitoring and accounting of economic activity.

Key words: farms, agricultural enterprises, priority areas, development, system management, components, monitoring, accounting and analytical support.

Дата надходження до редакції: 17.10.2019 р. 